\title{
Sauadega jumalus - problemaatiline kuju Mochika usundis.
}

\author{
$\underline{\text { Tarmo Kulmar }}$
}

Mochica kultuur on Peruu Kolumbuse-eelsete tsivilisatsioonide seas üks vanemaid ja probleemiderikkamaid. Tema tuumikala asus põhjarannikul Moche jõe orus, mitte väga kaugel tänapäeva Trujillo linnast. Nagu see on tavaline Peruu rannikuriba kõrgkultuuride puhul, elasid ka motshikad vaid mõnes oaasis, mis olid tekkinud rannikujõgede orgudesse. Neid oaase lahutas üksteisest mitmekümne kilomeetri laiune elutu kõrbevööde. Samal ajal võimaldavad orud, mida jõed reeglipäraselt üle ujutavad, oma elanikele rikkalikku saaki, ka meri on oma andide poolest siin üks heldemaid kogu maailmas.

Esimesed mälestusmärgid motshikate kultuurist avastati Peruu rahvusliku arheoloogiateaduse ühe rajaja, saksa arheoloogi Max Uhle poolt 1900. aastal. Tookord, mil Peruu vanim tsivilisatsioon, Chavín, oli veel avastamata, postuleeris Uhle nn immigratsionistliku teooria, mille järgi on Peruu tsivilisatsioonid, nende seas ka Mochica, saanud oma algmõjustused Meso-Ameerikast. Pärast Julio Tello avastusi 1919. a pääses maksvusele juba autohtonistlik Peruu tsivilisatsiooni tekketeooria. Mochica kultuurgi võrsus piirkonnas, mis oli varem kuulunud Chavíni mõjusfääri. Võõrmõjusid on motshikate puhul otsitud hiljemgi, sest rikkalik inimkujuline keraamika näitab, et motshikate inimkujutiste tüübis leidub nii mongoliidseid kui ka negroidseid jooni. Horkheimer pooldab näiteks migratsioonilainet, mis peaks olema saabunud Melaneesia kaudu Ida-Aasiast. Siiski on ülekaalus antropoloogiline tüüp, mis sellise arvamuse kahtluse alla seab (Busto s. a,: 143). Motshikad kõnelesid yunga-indiaanlaste keelt, mille esimese grammatika koostas juba 1644. a Fernando de la Carrex.

Tänapäeval Peruus käibiva arheoloogilise periodiseeringu järgi kuulub Mochica kultuur nn varajasse vaheperioodi ehk klassikaliste kõrgkultuuride perioodi (200 pKr - 700 pKr). Mochica kultuuri algus paigutatakse viimaste arheoloogiliste andmete alusel küll mõnevõrra varasemasse aega, juba II sajandisse eKr; kultuuri lõpp on samuti nihutatud umbes 800. aastani.

Mochica kultuuri tekkimisel ei saa alahinnata Peruu vanima tsivilisatsiooni, Chavíni mõjusid. Tegemist oli arenenud klassiühiskonnaga, mis jagunes ülikkonnaks, maaharijaiks ja orjadeks. Motshikatel oli arenenud põlluharimine, kalastus, käsitöö, kaubandus, meresõit ja metallurgia. Kultuuri kõrgaeg I aastatuhande keskpaigast alates on seotud sõjalise ekspansiooniga. Eriti tuntud on motshi-kate antropomorfne keraamika, milles avalduvaid mütoloogilisi ja sotsiaalseid süzheesid võib pidada kogu Peruu tsivilisatsiooniloo jooksul selle kunstiala tipuks.

Põhiallikana motshikate ühiskonna, ajaloo ja religiooni tundmaõppimiseks tuleb eelkõige kõne alla arheoloogiline leiumaterjal. Seda on kasutanud ka käesoleva artikli autor. Lisaks Peruu muuseumide kollektsioonide uurimisele ja autori enda fotomaterjalile on alljärgnevas rohkesti kasutatud Berezkini teose illustratsioone (Berezkin 1983).

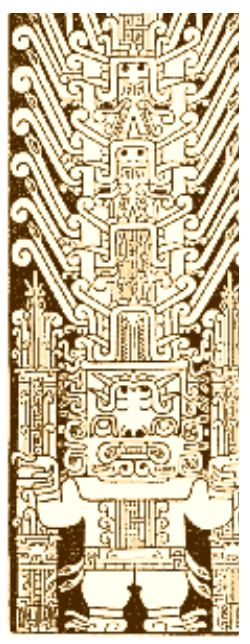


Mochica religioonis on võimalik eristada 4 suurt nähtuste kompleksi:

1. preesterlik-sõjaline kultus kui ametlik religioon,

2. samanistlik kui individuaalse maagilise iseloomuga praktika,

3. mütoloogilised motiivid,

4. surnutekultus (Berezkin 1983: 143-145).

Antud teema käsitlemisel on vaatluse all eelkõige ametlik religioon oma väljakujunenud panteoniga. Mütoloogilisi maailmapilte on raske võrrelda, kuna Chavíni omast on meil liiga vähe informatsiooni. Võime vaid Krickebergi alusel konstateerida, et Chavíni ja Mochica maailmapiltide vahel võis olla seoseid (Trimborn 1961, 132-133).

Sauadega jumalus ilmub esmakordselt Peruus Chavíni ajastul (900 eKr - 200 pKr). Tema klassikaline kuju on tuntud nn Raimondi steeli järgi (vt joonis A). Tegemist on jumalusega, kes hoiab mõlemas käes saua või keppi. Muud välised tunnusjooned võivad kultuuriti varieeruda. Valitseb arvamus, et sauadega jumalus kujutas endast taevast üliolendit, taevajumalat, kes hiljem omandas üha enam äikesejumala jooni. Chavínist levis sauadega jumaluse austamine üle kogu Peruu. Oli ajastuid, mil tema tunnusjooni oli võrdlemisi vähe või peaaegu üldse polnud leida, sh varajase vaheperioodi rannikutsivilisatsioonid. I aastatuhande lõpusajanditel $\mathrm{pKr}$ kerkib sauadega jumalus taas esiplaanile. Eriti iseloomulik on sauadega jumalus keskmise horisondi (800 - $1100 \mathrm{pKr})$ religioonides, kõigepealt Tiahuanaco kultuuris (100-1100) Altiplano kiltmaal Lõuna-Peruus, kus ta kanab nime Wiracocha (vt foto B). Hilise horisondi ehk inkade riigi (1438-1532) religioonis, kus taevane üliolend Pachacamak on muutunud deus otiosus'eks ja usundi raskuskeskmes seisab päikesekultus, on sauadega jumaluse olemasolu vaid aimatav ja teda võib täheldada pigem mütoloogilistes kihistustes. Kuna Mochica kultuur kuulub varajasse vaheperioodi, ongi sauadega jumaluse olemasolu selles religioonis olnud problemaatiline. Tegelikult ei ole olemas käsitlusi, mille autorid oleksid veendunud sauadega jumaluse olemasolus motshikate juures.

Samal ajal oleks sauadega jumaluse leidmine motshikate juures ootuspärane, sest:

1. esimene religioon, kus sauadega jumalus esile kerkis, oli Chavín.

2. Chavini kultuuri kolle asus Põhja-Peruu mägialadel.

3. Mochica tsivilisatsiooni kolle asus Põhja-Peruus, tõsi küll, mitte mägedes, vaid rannikul.

4. alad, kus tekkis Mochica tsivilisatsioon, kuulusid Chavíni mõjupiirkonda.

5. materiaalses kultuuris on Chavíni ja Mochica vahel olemas kultuuriline järjepidevus.

6. Teatud sarnaseid kultuurielemente on võimalik leida ka Chavíni ja Mochica'le järgnenud Põhja-Peruu kõrgkultuuride vahel. Siin olgu ära nimetatud eelkõige Chimú.

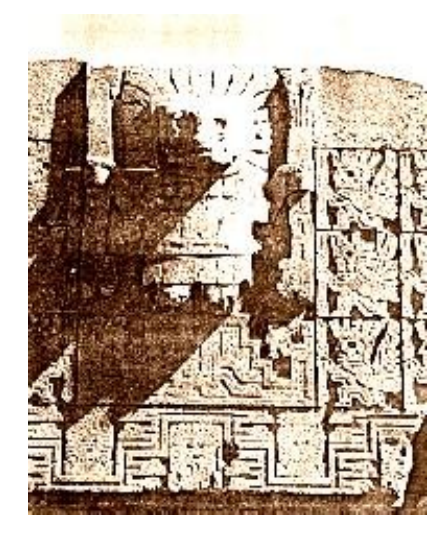

Kuna Mochica kultuur on Chavíni üks olulisemaid järglasi ja pärijaid ning Chavini mõjud Mochica materiaalsele kultuurile on vaieldamatud, siis on tegelikult üllatav, et sauadega jumalust kui mütoloogilist tegelast ei ole motshika religioonis seni avastatud.

Milliseid uskumusvaldkondi võib Mochica ikonograafias tegelikult leida? Järgnevalt ei peatuta keerukatel mütoloogilistel süzheedel, mille tõlgendamine ei puutu praegu asjasse ja mille üks pädevamaid asjatundjaid peruanistikas on vene uurija Berezkin. Olgu vaid nimetatud, et nendes süzheedes esineb väga tihti nn kiirtega jumalus. Kiirtega jumalusel leiab Kelm olevat kuujumaluse jooni, mistõttu on võimalik leida seoseid Chimú kultuuri religiooni peajumala, kuujumal Si'ga (Kelm 
1990: 526). See ei ole üllatav, sest hilise vaheperioodi (1100-1438) üks tähtsamaid riike Chimú tekkis samas piirkonnas, kus varem asus Mochica kultuuri keskus, mistõttu on nende kahe kultuuri järjepidevus vaieldamatu.

\section{Illustreeriv materjal koos selgitustega}

\section{Grupp 1.}

Nn neljanäoline deemon, nn konn-jaaguar, nn Recuai loom ja nn jumalus koletise seljas (joonised 1-4) Siin võib tähele panna mitmesuguseid erinevaid mõjustusi. Neljanäolise deemoni ja konn-jaaguari motiive võib leida juba Chavíni ikonograafias. Neljanäolist deemonit meenutavat olendit kohtab Chavíni perioodi savinõudel. Mis puutub konna-motiivi, siis konn-jaaguar on ilmselt olnud Chavíni mütoloogias oluline kuju. Konn-jumalus esineb Chavíni jumalaid kujutavate skulptuuride seas (vt foto C) Nn silmaolend viib meid tagasi varajase horisondi perioodi, nimelt Lõuna-Peruus paiknenud Paracase kultuuri, mis oli Chavíniga samaaegne ja mille usundi nn cavernase perioodi iseloomustasid

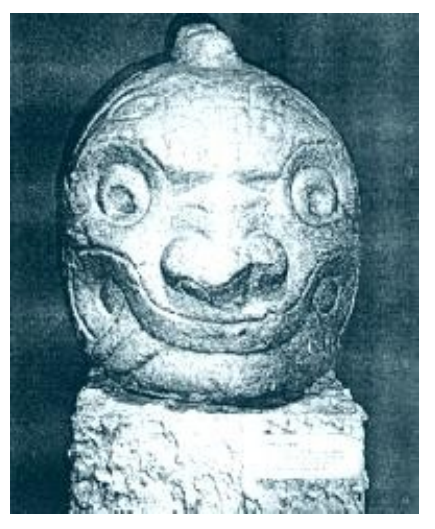
tugevad Chavíni mõjud. Suuresilmaline jumalus on Paracasele iseloomulik mütoloogiline olend, mille kuju tegi läbi mitmesuguseid muutusi (vt. foto D) Samal ajal on silmaolendi kujus ja samuti savinõu ornamentikas võimalik leida Recuai koletise jooni. Recuai kultuur on Chavíni hilisperioodiga samaaegne ja ta on paiknenud nii Põhja-Peruu mägi- kui ka rannikualal. Tasub pöörata tähelepanu nii konn-jaaguari kui ka silmaolendi ühele keraamilisele iseärasusele, nimelt torukujulisele sangale, mis on jällegi tüüpiliselt Chavínile omane joon. Joonisel 4 kujutatud jumalus merekoletise seljas on seevastu ilmselt Mochica kui rannikukultuuri enda päritoluga. Üks Mochica hilise perioodi taoline keraamiline muistis on eksponeeritud Limas Amano muuseumis (vt foto E) Kokkuvõttes annavad grupi 1 joonised tunnistust olulistest varasematest mõjudest Mochica religioonile, kusjuures eriti ilmsed on Chavíni mõjud.

\section{Grupp 2}

\section{(joonised 5-9)}

$\underline{\text { Joonisel } 5}$ on kujutatud jumalus taevakehadega ja taevamadu. Joonisel 6 hoiab jumalus ülal taevamadu. $\underline{\text { Joonisel } 7}$ võitleb jumalus draakoni ja pikajuukselise deemoniga, joonisel 8 toimub võitlus jumaluse ja mollusk-draakoni vahel, joonisel 9 asuvad jumalused taevakehade (tähtede) keskel. Need motiivid on kõige ilmsemalt seotud motshikate taevase üliolendiga. Nimelt oli motshikatel juba varasemast perioodist teadaolev solaarne, ilmselt päikesejumala joontega taevajumal (Kelm 1990: 526). Siin võib kohata motiive, mis on tuntud ka paljudest Vana Maailma religioonidest, nagu taevamadu (või ka maailmamadu), samuti taevajumala võitlus kaosekoletise või draakoniga, kelle kehast luuakse hiljem maailm. Loomulikult on lisandunud müüdisüzheele spetsiifilised Mochica jooned. Motiivi vanusele viitab joonise 7 ülaosas kujutatud Recuai koletis, mis on tunduvalt varasem ja osutab taas varasematele mõjudele, mis võivad ulatuda kuni Chavínini. See, et taevamadu esineb ka sootuks hilisemas inkade kosmogoonias, näitab omakorda, et Peruu religioonide vahel võib tähele panna kultuurilist järjepidevust kogu Peruu Kolumbuse-eelse tsivilisatsiooni kahe ja poole tuhande aastase arenguloo vältel. Kokkuvõttes näitavad grupi 2 joonised taevajumala ilmset olemasolu Mochica religioonis, kusjuures saab selgeks asjaolu, et Mochica taevajumalal puuduvad sauadega jumala välised tunnusjooned, mis olid eriti tähtsad Chavíni religioonis ja saavad taas olulisteks hilisemas Tiahuanaco religioonis. 
Tahes-tahtmata tuleb nüüd oletada ühte kahest. Esiteks - sauadega jumalus puudus Mochica religioonis üldse. Sellele räägivad aga vastu väga tugevad Chavíni mõjud. Teiseks - sauadega jumalus oli Mochica religioonis olemas, kuid sootuks teistsugusel kujul ja teistsuguste funktsioonidega jumalana kui Chavínis.

\section{Grupp 3 (joonised 10-17)}

Nendel joonistel võime näha jumalust mitmesugustes situatsioonides, mis on seotud taimekasvuga: jumalus kõpla ja maisivarrega tähtede keskel (joonis 10) jumalus kõpla ja maisivarrega (joonis 11) jumalus taimede ja madudega (joonis 12) jumalus maisitõlvikutega (joonis 13) jumalus maisitõlvikute taustal (joonised $\underline{14}$ ja $\underline{15}$ ), jumalus maisivarre, teradekoti ja kahe maoga (joonis 16) ja jumalus kõpla ja külvajapoisiga (joonis 17) Siin on tegemist viljakuskultuslike motiividega, mis on kõige otsesemas seoses maaviljelusega. Põlluharimine oli Mochica kultuuris tähtis elatisallikas ja Moche jõe orus ning naaberorgudes olid selleks olemas ka kõigiti sobivad tingimused. Samuti näitab Mochica ühiskonna analüüs ainuüksi keraamikal kujutatu põhjal, et motshikatel oli olemas väga arvukas maaharijate kiht. Pealegi tundub loogiline arvata, et motshikatel kui hilisemal tsivilisatsioonil olid olemas mõnevõrra edasiarenenumad ja produktiivsemad maaharimismeetodid kui varasemas Chavínis, samuti soodustasid seda Moche jõe oru viljakad loodusolud ja palju enam kui Chavíni raskesti haritavatel mäenõlvadel. Siit on võimalik edasi järeldada, et motshikatel pidi kindlasti olemas olema rikkalik agraarmütoloogia ja palju enam välja kujunenum viljakuskultuslik panteon kui seda oli Chavínis. Juhul kui Chavíni kultused levisid Mochica aladele, pidid uued religioonivormid Mochica tingimustes läbi tegema teatud mutatsioone. Antud materjali alusel on võimalik ka oletada, millises suunas. Eriti oluline on jälgida jooniseid 10, 11 ja 12. Maisijumal või viljakusjumal hoiab siin mõlemas käes oma atribuute - kõblats ja maisivart või maisitaimi. Need on vaid mõned motiivid, kuid Mochica arvuka ja hästisäilinud keraamika uurimine võimaldab selliseid motiive kindlasti palju enam leida. Nimelt saab üha ilmsemaks, et Chavini sauadega jumalus kui taevajumal on Mochica kultuuris omandanud agraarkultusliku jumala jooned. Joonisel 10 seisab maisijumal oma atribuutidega veel tähtede keskel. Tundub, et see motiiv kuulub vanemate hulka ja annab tunnistus perioodist, mil sauadega jumalus oli seotud ka solaarmütoloogiaga. Joonistel 12 ja 16 esinev madu lubab teatud reservatsioonidega kaudselt oletada seotust taevamütoloogiaga. Teistel joonistel enam taevamütoloogilisi lisandeid ei ole. Võimalik, et need on $\mathrm{ka}$ hilisemad ja jumaluse funktsioonide niisuguse muutumise poolt räägib asjaolu, et Mochica religioonis oli olemas omaenda taevajumal, kel oli kindlapiiriline tähendus ilmselt päikesejumalana, oma väljakujunenud mütoloogia, ja kes lihtsalt enam täiendavaid lisandusi ei vajanud. Küll aga vajas sellist mutatsiooni arenevat maaviljelust sümboliseeriv maisikasvujumalus, kes oli omakorda seotud vihma ja niiskuse ja seda ahelat pidi omakorda taevaga. Kokkuvõttes osutavad grupi 3 joonised küllalt suure tõenäosusega asjaolule, et motshikate maisikasvujumalus omandas ajapikku sauadega jumaluse jooned ja funktsioonid, mis olid Chavínis kuulunud hoopis taevasele üliolendile.

Käesolev vaatlus on muidugi vaid üks Mochica ikonograafia tõlgendamise võimalusi. Samal ajal võimaldab see vaatlus teha oletuse, et Chavíni sauadega jumalus oli Moches muutunud agraarjumaluseks, millisesse funktsiooni ta motshikate sootuks teistsuguseid looduslikke ja ühiskondlikke tingimusi arvestades ka palju enam sobis. Teiselt poolt näitab selline oletus veelgi tugevamana kultuurilise järjepidevuse olemasolu Chavíni ja Mochica vahel, kui seda seni on arvatud. 


\section{Kirjandus}

Berezkin, Yuri. 1983. Mochica. Tsivilizatsiya indeytsev Severnogo poberezija Peru v I-VII vv. Leningrad: Nauka.

Busto Duthurburu, Jose Antonio del. Peru Pre-Incaico. Lima: Editorial Universo S. A., s. a. Kelm, Antje. 1990. Grundzüge der Religionen des zentralen Andenraumes. - Altamerikanistik. Eine Einführung in die Hochkulturen Mittel- und Südamerikas. Hg. Ulrich Köhler. Berlin: Dietrich Reimer Verlag.

Trimborn, Hermann. 1961. Die Religionen der Völkerschaften des südlichen Mittelamerika und das nördlichen und mittleren Andenraumes. - Die Religionen des alten Amerika. Hg. W. Krickeberg. Stuttgart: Kohlhammer Verlag. 